\title{
PENGOLAHAN SAWI HIJAU MENJADI MIE HIJAU YANG MEMILIKI NILAI EKONOMIS TINGGI DI DESA SUKAMANIS KECAMATAN KADUDAMPIT KABUPATEN SUKABUMI
}

\author{
Siti Alifah1), Anita Nurfida 2) , Aditya Hermawan 3) \\ ${ }^{1,2,3}$ Program Studi Teknik Industri, Fakultas Teknik, Universitas Indraprasta PGRI Jakarta \\ Jl. Raya Gedong Jakarta Timur \\ * Penulis Korespodensi : nadiva87@gmail.com
}

\begin{abstract}
Abstrak
Sawi hijau merupakan salah satu jenis sayur-mayur yang memiliki masa simpan yang tergolong singkat. Sawi hijau akan cepat menguning dan membusuk dalam waktu dua sampai empat hari jika tidak dilakukan pengolahan dan pengawetan lebih lanjut. Untuk memberikan nilai tambah dan mengurangi waktu pembusukan, sawi dapat diolah lebih awal sebelum membusuk. Tujuan kegiatan ini untuk memberikan penyuluhan pengolahan sawi hijau menjadi mie hijau yang bercita rasa tinggi dan awet, sehingga dapat menambah kesejahteraan para petani sayur, khususnya sawi hijau di desa Sukamanis, Kecamatan Kadudampit, Kabupaten Sukabumi. Kegiatan ini juga memberikan pemahaman kepada petani, bahwa produk pertanian yang segar dan penuh dengan kandungan mineral bagi tubuh manusia. Metode yang digunakan dalam pelaksanaan pengabdian masyarakat dengan observasi langsung dan pengadaan workshop yaitu tim pengabdi langsung datang ke lokasi kegiatan abdimas untuk memperoleh data awal sebagai bahan pertimbangan dalam pelaksanaan kegiatan. Hal ini kami lakukan pada saat menjelang maupun saat kegiatan berlangsung. Observasi berguna untuk mengetahui kondisi ibu-ibu PKK dan pengolahan sawi hijau pasca panen. Hasil yang dicapai para peserta telah memahami bahwa sawi hijau memiliki kandungan gizi yang banyak manfaat bagi kesehatan dan memahami bahwa sawi hijau dapat diolah menjadi bahan makanan seperti mie sawi/ mie hijau yang mempunyai masa simpan lebih lama dan memiliki nilai ekonomis lebih tinggi.
\end{abstract}

Kata kunci: Mie hijau, Pengolahan, Produk, sawi.

\begin{abstract}
Green mustard is one type of vegetable that has a relatively short shelf life. Green mustard will quickly turn yellow and rot within two to four days if no further processing and preservation is carried out. To provide added value and reduce the time of decay, mustard must be processed earlier before rotting. The purpose of this activity is to provide counseling on the processing of mustard greens into green noodles that have high taste and durability, so as to increase the welfare of vegetable farmers, especially mustard greens in Sukamanis village, Kadudampit sub-district, Sukabumi district. This activity also provides understanding to farmers, that agricultural products are fresh and full of mineral content for the human body. The method used in the implementation of
\end{abstract}


community service by direct observation is that the service team directly comes to the location of the abdimas activity to obtain preliminary data for consideration in the implementation of the activity. We do this when we approach or when the activity takes place. Observation is useful to determine the condition of PKK mothers and post-harvest mustard greens processing. The results achieved by the participants had understood that mustard greens contain many nutritional benefits for health and understood that mustard greens can be processed into foodstuffs such as mustard greens / noodles that have a longer shelf life and have higher economic value.

Keywords: Green noodles, Mustard greens, Processing, Products

\section{Pendahuluan}

Era modern saat ini kesadaran akan pentingnya makanan sehat telah tumbuh dikalangan masyarakat, sehingga dalam pemilihan jenis bahan makanan tidak hanya sekedar enak, namun juga sehat. Sawi hijau adalah bahan makanan nabati yang sudah biasa dikonsumsi oleh masyarakat Indonesia, karena sawi hijau merupakan salah satu jenis sayur-mayur yang mudah dibudidaya, harganya sangat terjangkau dan memiliki kandungan gizi tinggi yang dibutuhkan oleh tubuh. Akan tetapi sawi mempunyai masa simpan yang tidak tahan lama dan mudah menguning dalam tiga sampai empat hari. Oleh karena itu perlu dilakukan pengolahan lebih lanjut menjadi bahan makanan produk lain yang memiliki masa simpan lebih lama dan nilai ekonomis yang lebih tinggi.

Pengolahan sawi hijau menjadi bahan makanan lain, seperti mie hijau memerlukan pengetahuan dan keterampilan yang lebih, sehingga sawi hijau dapat dimanfaatkan menjadi bahan makanan lain yang mampu meniingkatkan nilai ekonomis dan diharapkan dapat meningkatkan kesejahteraan petani sawi hijau di Desa Sukamanis, Kecamatan Kadudampi, Kabupaten Sukabumi.

Beberapa permasalahan yang dihadapi oleh ibu-ibu PKK di Desa Sukamanis adalah kurangnya pengetahuan masyarakat tentang kandungan gizi yang terdapat didalam sawi hijau yang banyak dibudidaya oleh masyarakat Desa Sukamanis dan kurangnya pengetahuan dan keterampilan masyarakat Desa Sukamanis untuk mengolah sawi hijau yang berlimpah pada saat masa panen tiba menjadi bahan makanan lain yang memiliki masa simpan lebih lama dan nilai ekonomis lebih tinggi, yaitu mie sawi sehingga diharapkan dapat meningkatkan kesejahteraan petani sawi hijau.

Sawi hijau merupakan suku sawi-sawian atau Brassicaceae, dikenal pula sebagai caisim, caisin, atau sawi bakso, sayuran ini mudah dibudidayakan dan dapat dimakan segar atau diolah menjadi asinan, lalapan, dan berbagai masakan lainnya. Sawi hijau umumnya dikonsumsi dalam bentuk olahan karena sawi mentah rasanya pahit karena ada kandungan alkaloid carpaine.

Tanaman sawi tahan terhadap air hujan, sehingga dapat ditanam sepanjang tahun. Pada musim kemarau yang perlu diperhatikan adalah penyiraman secara teratur, tanaman ini cocok bila di tanam pada akhir musim penghujan. Daerah penanaman yang cocok untuk sawi hijau adalah mulai dari ketinggian $5 \mathrm{~m}$ sampai dengan $1.200 \mathrm{~m}$ di atas permukaan laut. Namun biasanya dibudidayakan pada daerah yang mempunyai ketinggian $100 \mathrm{~m}$ sampai $500 \mathrm{~m}$ di atas permukaan laut. Umur panen sawi paling lama 40 hari, dan paling pendek 30 hari dan terlebih dahulu melihat fisik tanaman seperti warna, bentuk, dan ukuran daun. Cara panen ada 2 macam yaitu mencabut seluruh tanaman beserta akarnya dan dengan memotong bagian pangkal batang yang berada di atas tanah dengan pisau tajam (Margiyanto, 2007). 
Klasifikasi tanaman sawi hijau dapat dijabarkan sebagai berikut: Kingdom: Plantae (Tumbuhan); Divisi: Spermatophyta; Subdivisi: Angiospermae; Kelas: Dicotyledone; Ordo: Rhoeadales (Brassicales); Famili: Cruciferae (Brassicaceae); Genus: Brassica serta Spesies: Brassica rapa I. Subsp. Perviridis Bayley (Margiyanto, 2007). Sayuran sawi hijau disajikan pada Gambar 1.



Gambar 1. Sawi Hijau

Sumber: Anonim (2012)

Sawi hijau sebagai bahan makanan sayuran mengandung zat-zat gizi yang cukup lengkap sehingga apabila dikonsumsi sangat baik untuk mempertahankan kesehatan tubuh. Sawi hijau merupakan sayuran yang bermanfaat untuk membantu mencegah dari terserangnya penyakit kanker, hal ini disebabkan karena dalam sawi hijau mengandung senyawa fitokimia khususnya glukosinolat yang cukup tinggi. Dengan rutin mengkonsumsi sawi hijau mampu menurunkan resiko terserangnya kanker prostat. Kandungan gizi sawi hijau (Brassica rapa I. Subsp. Perviridis Bayley) setiap $100 \mathrm{~g}$ dapat dilihat pada Tabel 1.

Tabel 1. Kandungan gizi sawi hijau setiap $100 \mathrm{gr}$

\begin{tabular}{clc}
\hline No & Komposisi & Jumlah \\
\hline 1 & Protein $(\mathrm{g})$ & 2,3 \\
2 & Lemak $(\mathrm{g})$ & 0,4 \\
3 & Karbohidrat $(\mathrm{g})$ & 4,0 \\
4 & Kalsium $(\mathrm{mg})$ & 220 \\
5 & Fosfor $(\mathrm{mg})$ & 38,0 \\
6 & Besi $(\mathrm{mg})$ & 2,9 \\
7 & Vitamin A $(\mathrm{mg})$ & $1.940,0$ \\
8 & Vitamin B $(\mathrm{mg})$ & 0,09 \\
9 & Vitamin C (mg) & 102 \\
10 & Energi $(\mathrm{kal})$ & 22,0 \\
11 & Serat (g) & 0,7 \\
12 & Air $(\mathrm{g})$ & 92,2 \\
13 & Natrium $(\mathrm{mg})$ & 20,0 \\
\hline
\end{tabular}

Sumber: Direktorat Gizi, Departemen Kesehatan RI (2012) 
Sawi hijau memiliki banyak manfaat bagi kesehatan. Sawi hijau kaya akan vitamin A, B, C, E, dan K. Sawi juga mengandung karbohidrat, protein, dan lemak baik yang berguna untuk kesehatan tubuh. Zat lain yang terkandung dalam sawi adalah kalsium, kalium, mangan, folat, zat besi, fosfor, teptofon, dan magnesium. Kandungan non-gizi yang ada dalam sayur sawi adalah serat atau fiber yang kadarnya cukup tinggi. Karena kandungan gizi inilah, sawi termasuk sayuran ajaib yang dapat berfungsi baik untuk mencerdaskan otak.

Lebih jauh, kandungan vitamin paling tinggi yang ada pada sayur sawi adalah vitamin K. Vitamin ini sangat berguna untuk pembekuan darah, sehingga luka akan cepat mengering. Untuk kandungan vitamin C-nya, kadarnya hampir sama dengan jeruk. Dengan vitamin C yang dikandungnya, sawi sangat bagus untuk menjaga daya tahan tubuh sehingga tidak mudah sakit.

Kandungan kalsium pada sawi juga cukup tinggi. Kalsium dalam sawi sangatlah bagus untuk pembentukan dan menjaga kualitas dan kesehatan tulang dan gigi, sehingga bisa menghambat tulang keropos atau osteoporosis. Manfaat lain yang tak kalah penting dari sawi adalah untuk menurunkan kadar kolesterol jahat penyebab stroke atau penyakit jantung yang mematikan, serta dapat menurunkan kadar gula darah penyebab kencing manis.

Secara kimiawi, sawi mengandung komponen kimia penghambat penyakit kanker. Sawi bisa menurunkan risiko terkena berbagai penyakit kanker, seperti kanker payudara, kanker prostat, kanker ginjal, kanker paru-paru, atau kanker kandung kemih. Serat pangannya yang cukup tinggi diyakini dapat membantu proses pencernaan pada perut secara baik. Sawi juga bermanfaat untuk mencegah terjadinya penyakit gondok. Sawi memiliki komponen kimia yang bisa mencegah pembengkakan kelenjar tiroid.

Menu kuliner berbahan mie selalu menjadi menu favorit semua kalangan, dari anak kecil hingga dewasa menyukai masakan mie, karena cita rasa mie yang menggugah selera, juga menu mie yang mengenyangkan dan praktis dibuat. Sudah banyak pelaku usaha yang menjajakan menu mie karena memang mie memiliki pangsa pasar yang besar. Jenis mie yang sering dikonsumsi oleh masyarakat sangat banyak macam dan variannya, dari mie daging, mie telor, mie instan, mie bihun dan jenis mie lainnya termasuk mie hijau yang terbuat dari sayur-mayur membuat mie memiliki kandungan gizi yang lebih tinggi. Jenis makanan olahan yang berbahan baku mie juga sangat banyak ragamnya, diantaranya mie ayam, mie ramen, mie goring, mie pangsit, mie Aceh, mie Jawa, dan jenis kuliner mie yang lainnya.

Manfaat mie yang memiliki banyak kegunaan untuk dijadikan bahan makanan olahan yang dimasak dengan berbagai cara, rasa serta cara penyajian yang beraneka ragam membuat mie banyak dijadikan peluang bisnis yang sangat menguntungkan. Oleh karena itu sangat mudah mencari penjual mie di sekitar kita, bahkan di komplek perumahan, pesta rakyat, pinggir jalan, pusat kota bahkan di mall besar sangat mudah kita jumpai penjual mie dengan menu dan resep yang unik dan menggugah selera.

\section{Metode}

Metode yang dilakukan dalam penelitian kegiatan Pengabdian Masyarakat ini melalui beberapa tahap, yaitu :

Observasi langsung yaitu tim pengabdi langsung datang ke lokasi kegiatan abdimas untuk memperoleh data awal sebagai bahan pertimbangan dalam pelaksanaan kegiatan. Hal ini kami lakukan pada saat menjelang maupun saat kegiatan berlangsung. Observasi berguna untuk 
mengetahui kondisi ibu-ibu PKK dan pengolahan sawi hijau pasca panen di Desa Sukamanis, menentukan materi dan alternatif solusi yang diperlukan dalam memberikan pemahaman tentang kandungan gizi sawi hijau, manfaat bagi kesehatan serta pengolahan sawi hijau menjadi produk bahan makanan lain yang memiliki masa simpan lebih lama serta memiliki nilai ekonomis lebih tinggi. Observasi sangat penting untuk mewujudkan kesuksesan kegiatan pengabdiaan masyarakat itu sendiri.

Workshop yaitu Memberikan pemahaman, materi-materi dan keterampilan yang berkaitan dengan kandungan gizi sawi hijau, manfaat sawi hijau bagi kesehatan dan pengolahan sawi hijau menjadi produk bahan makanan lain yang memiliki masa simpan lebih lama dan nilai ekonomis lebih tinggi kepada ibu-ibu PKK di Desa Sukamanis, sehingga diharapkan dapat meningkatkan kesejahteraan bagi masyarakat Desa Sukamanis, Kecamatan Kadundampit, Kabupaten Sukabumi.

\section{Hasil dan Pembahasan}

Kegiatan pelaksanaan pengabdian masyarakat dengan melibatkan Ibu-ibu PKK di Desa Sukamiskin, Kecamatan Kadudampit, Kabupaten Sukabumi sangat didukung oleh Kepala Desa dan jajarannya pada tanggal 21 Juli 2018. Tahap pertama adalah penjelasan materi yang disampaikan oleh tim abdimas dalam bentuk presentasi. Adapun materi yang disampaikan adalah sebagai berikut: (1) menjelaskan tentang kandungan gizi sawi hijau, (2) menjelaskan manfaat sawi hijau bagi kesehatan, (3) menjelaskan tentang pengelolaan sawi hijau menjadi produk yang yang memiliki masa simpan lebih lama dan nilai ekonomis lebih tinggi seperti mie hijau/ mie sawi.

Tahap berikutnya adalah sesi tanya jawab, kami memberikan kesempatan kepada para peserta untuk bertanya tentang berbagai hal yang belum dipahami tentang materi dan ternyata peserta sudah menyiapkan beberapa pertanyaan kepada tim abdimas. Setiap pertanyaan dari peserta, tim abdimas bisa menjelaskan dengan baik dan melakukan umpan balik kepada peserta yang bertanya mengenai kepuasan dari jawaban tim abdimas. Dengan adanya kegiatan pengabdian masyarakat ini memberikan ilmu pengetahuan yang baru kepada ibu-ibu PKK. Antusias warga dalam mengikuti kegiatan ini patut diapresiasi. Para peserta dapat memahami dengan baik proses pembuatan mie hijau. Berikut ini rangkuman peserta ,serta target yang telah dicapai ditampilkan pada tabel 2.

Tabel. 2. Tabel Hasil Produksi

\begin{tabular}{ccccc}
\hline No & NAMA KELOMPOK & TARGET PRODUKSI & REALISASI & KET \\
\hline 1 & Melati & $12 \mathrm{Kg} /$ hari & $100 \%$ & \\
2 & Flamboyan & $10 \mathrm{Kg} /$ hari & $79 \%$ & \\
3 & Kamboja & $10 \mathrm{Kg} /$ hari & $75 \%$ & \\
4 & Mawar & $12 \mathrm{Kg} /$ hari & $100 \%$ & \\
5 & Bougenvil & $11 \mathrm{Kg} /$ hari & $50 \%$ & \\
6 & Adenium & $12 \mathrm{Kg} /$ hari & $100 \%$ & \\
\hline
\end{tabular}

Sumber : Hasil kegiatan yang diolah (2018).

Tabel diatas proses perlu ditingkatkan lagi, sehingga target dapat tercapai. Kegiatan ini diawali dengan penjelasan materi yang disampaikan oleh tim abdimas yang bertugas sebagai moderator, 
adapun materi yang disampaikan adalah sebagai berikut: (1) Menjelaskan tentang pengembangan produk, (2) menjelaskan kelebihan produk kue basah ibu-ibu PKK, (3) menjelaskan pemasaran produk kue basah Ibu-ibu PKK.

Tahap berikutnya adalah sesi tanya jawab dan ternyata peserta sudah menyiapkan beberapa pertanyaan kepada tim abdimas. Setiap pertanyaan dari peserta, tim abdimas bisa menjelaskan dengan baik dan melakukan umpan balik kepada peserta yang bertanya mengenai kepuasan dari jawaban tim abdimas. Sehingga dapat disimpulkan kegiatan ini dapat meningkatkan pengetahuan dan wawasan ibu-ibu PKK tentang kandungan gizi pada sawi hijau dan manfaat sawi hijau bagi kesehatan. Selain itu, diharapkan ibu-ibu PKK dapat mengembangkan produk sawi menjadi bahan makanan yang mempunyai masa simpan lebih lama dan nilai ekonomis yang lebih tinggi yaitu mie sawi/ mie hijau

\section{Simpulan}

Kegiatan pengabdian masyarakat yang dilakukan ini sangat perlu dan dapat dirasakan manfaatnya oleh ibu-ibu PKK di Desa Sukamanis, Kecamatan Kadundampit, Kabupaten Sukabumi, karena menambah wawasan dan ketrampilan ibu-ibu PKK.Dari kegiatan diaas dapat disimpulkan bahwa, peserta telah memahami bahwa sawi hijau memiliki kandungan gizi yang banyak dan bermanfaat bagi kesehatan, peserta dapat mengetahui dan memahami bahwa sawi hijau dapat diolah menjadi bahan makanan seperti mie sawi/ mie hijau yang mempunyai masa simpan lebih lama dan memiliki nilai ekonomis lebih tinggi. Sehingga diharapkan nantinya dapat meningkatkan kesejahteraan dan taraf hidup petani sawi di Desa Sukamanis, Kecamatan Kadudampit, Kabupaten Sukabumi. Dalam pelaksanaan pengabdian masyarakat ini, perlu komunikasi yang intensif agar para peserta khususnya ibu-ibu PKK yang memiliki potensi untuk menghasilkan produk baru dari sawi hijau, seperti mie hijau dapat terus termotivasi dan semangat.

\section{Ucapan Terima Kasih}

Ucapan terimakasih kepada semua pihak yang telah membantu kegiatan ini, diantaranya , Kepala Desa Sukamanis kecamatan Kadudampit kabupaten Sukabumi, dan semua masyarakat dan pihak yang ikut mendukung.

\section{Daftar Pustaka}

Alifah, S., Narsih, D., \& Widiyarto, S. (2019). Pengaruh Metode Partisipatori Dan Minat Belajar Terhadap Kemampuan Berwirausaha Siswa Smk. Lectura: Jurnal Pendidikan, 10(1), 66-81.

Darwis, K., \& Anwar, A. R. (2018). Pelatihan Olahan Sawi Hijau Untuk Menumbuhkan Jiwa

Wirausaha Pada Kelompok Wanita Tani Mt Al Muhajirin Di Kelurahan Tamalanrea Jaya. Martabe: Jurnal Pengabdian Kepada Masyarakat, 1(2), 67-71.

Hugo, A. S., Sigit, W., \& Mohammad, R. (2019, January). The Village Fund Allocation: the Evaluation and Progression Program of Government. In 1st International Conference on Education and Social Science (ICESRE 2018). Atlantis Press. 
Margiyanto, E. 2007. Hortikultura. Bantul : Cahaya Tani.

Rukmana, I. H. R. (1994). Bertanam Petsai \& Sawi. Kanisius.

Suyana, N., \& Wulansari, L. (2019). Pembelajaran Karakter Melalui Pelaksanaan Idul Adha Pada Siswa Sma. Journal Of Empowerment Community (Jec), 1(2), 40-47.

Sunarmintyastuti, L., \& Widiyarto, S. (2019). Pelatihan Pembuatan Prakarya Dalam Rangka

Meningkatkat Minat Berwirausaha Siswa Mts. Matappa: Jurnal Pengabdian Kepada Masyarakat, 2(2).

Vernia, D. M., Widiyarto, S., Wulansari, L., \& Rusdi, M. (2018). Penyuluhan Dalam Meningkatkan Partisipasi Program Dana Desa. Prosiding Sembadha, 1(1), 72-78.

http://www.organisasi.org/1970/01/isi-kandungan-gizi-sawi-hijau-komposisi-nutrisi-bahanmakanan.html\#.Wxaatoq-mpo (diakses 2 Juni 2018 pk 09.25)

http://jajanpinggiran.blogspot.com/2016/07/resep-dan-cara-membuat-mie-hijau.html (diakses 3 Juni pk 20.15) 